\title{
The Development of Tarutung Into a City
}

\author{
Pertiwih Siahaan $^{1}$, Budi Agustono ${ }^{2}$ \\ ${ }^{2}$ Postgraduate in History of Science, Faculty of Cultural Studies, University of Sumatera, Indonesia \\ ${ }^{3}$ University of Sumatera, Indonesia \\ tiwi.siahaan@gmail.com
}

\begin{abstract}
This article discusses the history of the formation of the city of Tarutung. This article answers the problem of how the city of Tarutung developed after the arrival of Western colonialism in the form of religion, military, administration and economy which encouraged the development of Tarutung City. This study uses the historical method through four stages: heuristics (collection of historical sources); verification (source criticism); interpretation (historical analysis and interpretation); and historiography (writing history). Sources as historical data obtained from a number of documents and literature from the colonial to postcolonial period. This study found that the existing Tarutung city was formed into a traditional city which was used as a trading center from a durian tree that grew in the middle of the village with the Batak Toba socio-culture that was implemented before the arrival of Western colonialism. The arrival and colonial influence made the identity of Tarutung City begin to develop both in terms of social, economic, and cultural aspects while maintaining the traditional cultural elements that still exist.
\end{abstract}

Keywords

Tarutung Qty, traditional Qty, development of Tarutung

\section{Introduction}

Gegraphically, Tarutung is located in North Sumatra, precisely in the north western part of Lake Toba. Tarutung is located in a Silindung rura surrounded by green hills and mountains, and is flanked by Siatas Barita and Mount Martimbang hills. Tarutung is a small village inhabited by the Batak-Toba people. The prevailing customary and cultural systems show that the village of Tarutung already has the characteristics of the formation of a traditional city. The background of the name Tarutung originates from a durian tree (Bona ni Tarutung) that grows in the middle of the village. Tarutung Village is the center of trade transaction activities carried out with local residents or also with immigrants from the Batak land area such as Humbang, Samosir, Tobasa and Dairi. At the location of the tree, over time it was used as a place for trade promises. Trade activities with the outside world have also been going on for centuries. Tarutung is located in a strategic location and is profitable for trading activities because it is a cross-section of the Toba road that must be passed.

The presence of Western colonization in the form of religion, military, administration, and economy was part of the driving force for the development of Tarutung City. Missionary activities that spread the gospel require security guarantees so that they can continue safely, in addition to that the Dutch government also has an interest in maintaining security and order for the indigenous people. These two interests are intertwined. The Dutch government found it easy because the zending's activities had indirectly made the Tarutung people's life more orderly.

The RMG zending mission that gave birth to a new civilization in Tarutung was reported in the Algemeen Handelsblad newspaper which reported the improvement of the 
RMG zending service that was developing in the Land of Batak. The RMG zending activity in Tarutung began when Ingwer Ludwig Nommensen moved to the Silindung valley, Tarutung in 1864 with the help of the king of Pontas Lumbantobing. In subsequent developments the city of Tarutung gradually passed into the hands of the Dutch military and administrative authorities starting in 1878. So in Staatsblad No. 353 that the city of Tarutung in 1879 was designated as a controleur for Onderafdeling Silindung. In this administrative area, the Dutch placed a controller who was given orders to carry out various activities of the colonial government.

This article aims to answer two problems, namely: (1) How did Tarutung develop into a city? (2) How was the physical development after the formation of Tarutung into a city?

\section{Research Methods}

This study uses historical methods. The research data were obtained from a number of colonial archives and other sources classified as primary and secondary sources which are relevant and contain historical evidence and facts. The focus of this research is the development of the city of Tarutung from colonial to post-colonial times. The temporal scope covers the colonial to post-colonial period, where in the post-colonial period it was the beginning of the development of the city of Tarutung towards a modern life due to the arrival of German missionaries and Dutch colonialism. Meanwhile, post-colonial is how the Tarutung people began to take over the colonial leadership to become the property of the Tarutung government after the end of the Dutch colonial period.

\section{Discussion}

\subsection{Tarutung before Entering the Netherlands}

Tarutung is a village located in Rura Silindung (Silindung Valley). Rura means valley, because the area is shaped like a valley or more like a cauldron when viewed from a higher place. Tarutung is surrounded by green hills and mountains, and is flanked by Bukit Siatas Barita and Mount Martimbang. A river named Aek Sigeaon stretches like dividing the city of Tarutung which flows its water, followed by Aek Situmandi to the open sea, the Indonesian Ocean. Regarding the origin of the name Tarutung, there are several versions that are used as references. In the Batak language dictionary, Tarutung means durian fruit. The people of Tarutung believe that the name Tarutung originates from a durian tree (Bona ni Tarutung) that grows in the middle of the village. Members of an ethnic group have a common history (ancestry), language, value system, customs, and traditions (Kholil, 2021).

Tarutung Village was the center of trade transaction activities around the 1800s which were carried out with local residents or also with immigrants from the Batak land area such as Humbang, Samosir, Tobasa and Dairi. In the location of the tree, over time it was used as a place for trade promises. This place was also used by the kings of Silindung as a partungkoan (meeting) place. In addition to its strategic location, it is also quite easy to know and remember, because it was the only tree that was the tallest and shady at that time, so it could be used as a benchmark for meetings.

Regarding the population before the arrival of the Europeans to Tarutung before the German missionaries came to the Batak tribal areas, there are several areas that already have a relatively large population. In the 1820 s the Toba Silindung area contained 82 villages with a population of between 80,000-100,000 inhabitants. This has been witnessed and reported in the travel reports of Richard Burton and Nathanel Ward which recorded what and how inland Tarutung was in their eyes. When they arrived at the village of Saitnihuta Tarutung, a grand 
meeting (bius) was held in the middle of the village of Saitnihuta which was attended by kings and the community of approximately 2000 people and there were about 20 or 30 villages in Tarutung, with the population in each village ranging from 20-60 people.

About two decades later, F. Junghuhn found a similar picture of the population. Junghuhn informed that in 1840 the population of Silindung was very dense. At that time there were $\pm 10,500$ inhabitants of the Silindung valley. The population is spread across the villages in Tarutung, including Simangambat, Liang, Banjarnahor, Sigotom, Pangaribuan, Bukit Sitarindok, Lumban Siagian, Hutagalong, Saitnihuta, Siandor-andor, Hutapea Banuarea, Parbubu Pea, Parbubu II, Parbubu Dolok, Hutatoruan VIII, Parbubu I, Hutatoruan I, Sosunggulon, Parbaju Toruan, Hapoltahan, Hutatoruan IV, Aek Sian Simun, Hutatoruan V, Hutatoruan VI, Hutatoruan XI, Hutatoruan IX, Hutatoruan X, Hutatoruan VII, Partali Toruan, Parbaju Tonga, Simamora, Hutagalung Siwalu ompu, Siraja Oloan, Hutauruk, Parbaju Julu, Partali Julu, Partali Julu, Sitampurung, Jambur Nauli, Sihujur, Hutatoruan III.

Another understanding of Tarutung, according to Bezemer, is that Tarutung is the capital of the Silindung section and one part of the Tanah Batak area in Tapanuli and is the residence of the chief assistant resident. On the map Taroetoeng Topographische Inrichting Batavia 1907 depicted Tarutung as the location of the residence of the head of the Dutch resident assistant. This Batak land began to be controlled by the Dutch Army, especially after the handover of West Sumatra by British control to the Dutch colonial government. So the Dutch set foot in Silindung and established their headquarters right in the center of the city of Tarutung which is now called Tangsi. The Dutch wanted to expand their territory in Batak lands by occupying the Tarutung region. This area is a very profitable area as a strategic cross-road Toba, Tarutung is passed to Sibolga, besides that, if you take another route, such as through Siborong Borong, you have to pass Balige. The traders who carried out trading activities near Tangsi, of course, benefited the Dutch military and their families who lived in Tangsi.

The Encyclopaedie van Nederlandsch-Indië describes Tarutung which is the capital of the Silindung section and one part of the Tanah Batak region in Tapanoeli and is the location of the chief assistant resident. To the south is Lake Toba, on the west side of the Silindung plain, at an altitude of $1076 \mathrm{M}$ above sea level. Tarutung is an important center for the entire Toba plain: zending chose Tarutung as a starting point for spreading Christianity to the Toba Batak people.

\subsection{RMG Zending Arrival in Tarutung}

Rheinische Missions-Gesellschaft is a German mission that focuses on the continents of Asia and Africa and educates evangelists in and based in Barmen, in the Rheinland region. The mission movement established four branches in the south of Lake Toba, in areas that were not yet monotheistic (Sipirok, Waringan, Bungabanda and Silindung). Zending RMG realizes that evangelism in coastal areas or those that have been controlled by the Dutch is not successful because the majority of the population in that area are Muslims. Because of that they immediately took the decision to start working in the interior of the Batak Land and until they arrived in Tarutung, which the colonial government called an independent area (onafhankelijk gebied). Zending RMG then opened a new evangelism in Sumatra called Battakmision or Mission-Batak.

On October 7, 1861 a new evangelistic area was opened in Sumatra, "Bataklanden" or Tanah Batak. This new evangelistic area was named "Battamission" which was later called "Batak mission" or "Mission - Batak". Batakmission in this case means an association of all RMG delegates in Tanah Batak and their assets which cover all pargodungan and 
congregations as well as indigenous servants. The date of birth of the Batak Mission was greeted by the evangelists RMG delegation in Tanah Batak.

Mission was set on October 7, 1861 to coincide with the date of the first meeting of the evangelists RMG delegation in Tanah Batak. The birthday of the Batak Mission was greeted by the management of sending RMG (Rheinischen Missions- Gesellschaft) in Germany with joy.

The RMG zending determines the place of service in Tanah Batak. Namely Klam accepts Sipirok as a place of service; Betz in Bungabondar which is not far from Sipirok; while Van Asselt and the young evangelist Heine pioneered evangelism in the northern part of the Batak Land which was still free from Dutch colonial occupation. After the opening, it wasn't long before IL Nommensen joined them. Since their inception, missionaries have targeted the densely populated Toba and Silindung areas as areas for evangelism. While the colonial government did not appear to be anti-zending, on the contrary they were very supportive of evangelism efforts.

After the arrival of the Batakmission, there was rapid progress in the Batak Land as a whole. The progress that has occurred in the Batak Land, among others, is mainly in terms of improving services carried out by zenders, especially in the fields of education and health, which are considered very effective as a step in making an approach to the indigenous community as well as to facilitate their activities. The education system is a means of social stratification that opens up opportunities, especially for the lower classes, such as hatoban (slaves), and modern health to improve the welfare of society. The RMG zending mission that gave birth to a new civilization in Tarutung was reported in the Algemeen Handelsblad newspaper which reported the improvement of the RMG zending service that was developing in the Land of Batak.

\subsection{Physical Development of Tarutung City}

Physically, the development of a city can be characterized by its increasing population density, denser buildings, larger settlements, and more complete urban facilities that support the activities of its residents. Meanwhile, the city as a strategic area is always synonymous with the central point or central point of a process of public and state life, which contains various strategic functions including: center of government, center of culture and education, center of economic activity, center of information, and recreation and entertainment centers.

Administrative changes in the administration of a city government also result in the fulfillment of new needs for facilities that support and are in accordance with the administration of a government. Often this is manifested in the form of architectural works, urban spatial planning, and the circulation of the road network which function as a medium for conveying political messages from the authorities. This can be characterized both by the construction of facilities that are directly related to supporting government administration and indirect facilities that support the life of the people of the ruling class.

It can be said that the Tarutung region is experiencing a rapid modernization process. Development has begun to increase in various fields including education, trade and the economy. Several things that have developed since the Dutch came to power in Tarutung include the establishment of a market, the construction of a hospital, the establishment of schools, the construction of transportation routes for trade, and the construction of churches. The establishment of various new infrastructures in the end helped develop Tarutung into a city that has various important facilities in its area.

\section{a. Tarutung Market}

One of the most prominent activities since Tarutung's status changed into a city is the use of the market as a place to improve the community's economy. The market is a strategic 
place for people who depend on this business. Activities that take place in the market are one of the driving forces for the growth of the community's economy so that it greatly benefits the people of Tarutung.

Before the Dutch colonial era, Tarutung Market had grown as a market. At least that was witnessed by Burton and Ward, a British missionary who visited Tarutung in 18247 who was guided to the villages of Sait ni Huta and Onan Sitahuru. In the middle of the market grows a tree, a kind of ant that makes a nest in the tree, where the kings of the village meet (partungkoan) every market day. Onan Sitahuru is one of the onan (pecan, market, shopping and trading place). Many people who come from Simanduma Village do trading activities in the Tarutung market. Apart from the people from the village usually use horses (marhoda boban) and buffalo (padati) as means of transportation to bring agricultural products to the market (onan).

The presence of Onan Tarutung then turned off Onan Sitahuru. Because then the kings of the village, especially from the Siopat Pusoran group who were "friendly" to the Dutch, preferred to gather under the tarutung tree planted by the Dutch. So the city of Tarutung was centered there, and now the market in Tarutung is on Jalan Raja Saul Lumbantobing, Hutatoruan VI.

The existence of the market is becoming increasingly important with the increasing number and variety of people's necessities of life along with the entry and settlement of migrants from various ethnicities. In addition, export-import activities at government ports, inter-island trade, and inland areas at public ports also require storage containers

The development of the market in Tarutung gradually was very profitable for the local population, as it made traders from other areas such as those from Pahae and Saitnihuta villages. Traders around the Batak Land often made transactions together and exchanged the goods needed. The market in Tarutung is one of the places that is very busy with various activities of the population with many types of goods being traded.

The increase in market activity made trading activities not only around the Batak Land but also to the Island of Java (Batavia). In 1928 from the city of Tarutung, goods were sold, namely incense. In the newspaper, it was reported that the activity of the sale of sending incense to the Dutch East Indies was reported. The Frankincense Trader received 180 guilders for one first quality picol; while for low quality only 25 to 80 guilders per pikol. In 1928, Tapoenoeli and Palembang were exported to other regions in the Dutch East Indies for $2,891,000 \mathrm{~kg}$. Benzoin with a value of 2,288,000 guilders. The market is an important place in the economic activity of a society. The existence of Tarutung Market plays a role in developing the economy of a city. Therefore,

\section{b. Construction of Schools}

The education of the Tarutung people was very far behind in the period before the arrival of Christianity. However, after the entry of Christianity in the Land of Batak which was pioneered by the Zending, namely Zendelingen RMG from Germany, the education of the Tarutung community began to develop. The education received is a lesson in reading, writing and arithmetic just like education in Europe. The development of education in Tarutung took place quickly and rapidly in line with the influence of Zending, then causing the Tarutung community to be open to outside influences.

Meanwhile, the NICA-Dutch Government was getting easier to enter and control the Batak Land, which slowly began to receive education from Christianity. After entering the Dutch NICA government administration, they began to play a role in education in Tarutung. For the Tarutung area, the Dutch-NICA Government only provides subsidies for schools built by Zending that meet the standards. The management and educators are determined by the Zending party who manages them fully. The role of zending in the development of education 
is more evenly distributed among the disadvantaged layers of society. In this case it is evident that the number of schools built by zending and the community has increased in number. Changes in society in terms of education began to appear with the efforts of parents to send their children to a higher level. As well as the growing sense of prestige for higher education, so that people in whose parents have a sufficient economy to send their children to Batavia or to Europe (the Netherlands).

In addition to applying the Western model of education to the Batak community, the RMG zending also introduced services through schools organized by zending, so modern education was applied to Batak residents. The high literacy rate indicates that the magazines and leaflets are disseminated by the organization. The Batak people are becoming smarter, not only about church activities and Christian religious studies, but also on issues concerning government oral teaching.

Despite the fact that the zending school curriculum emphasizes Christian religious lessons, the quality of education provided is basically higher than the schools opened by the Dutch colonial government. The Dutch colonial government school only provided third grade, while the Zending School educated its pupils up to sixth grade. However, in subsequent developments the level of education offered by the Dutch colonial government was getting better.

After the arrival of the Batakmission, there was a rapid development in Tarutung. These developments were influenced in part by the relatively stable political conditions under colonial rule, which resulted in an increase in the people's economy. For the people of Tarutung, the colonial era was not only of negative value, but it also had a positive impact, especially in terms of education.

The developments that took place in Tarutung also benefited from the Christianization movement through the development of education as well as changing the way of life and the system of thinking of the people. The way of life that was previously closed in clan villages has begun to open up to a system of living together. In addition, a social-oriented system has begun to develop towards a modern organizational orientation that introduces formal status in the form of positions.

In the first years of the establishment of the school in Tarutung Batakmission, through its European and indigenous leaders, still experienced difficulties in instilling an understanding of the benefits of education for the local community. But gradually, people's interest quickly grew, and they often demanded greater learning opportunities and facilities than what zending provided.

The types of schools that were organized by the RMG and the Dutch colonial were:

1. Hollands Batakse School training school (since 1914 it became HIS) Vervolgschool then in the 1920s it became Vervolgschool, Yang I in Tarutung (1910) has a 5-7 years of education and is a subsidized school led by zendeling or teachers

2. The school for teacher education is Sikola Mardalan-dalan 1874

Volksschool or People's School. This school was founded by the colonial government, namely in Lumbansoit only consisting of two classes, namely class one and class two. Some of the children have graduated and then continue their education at the Mission Standaardschool in Hutabarat Village. To travel to the village, they use the path over the Aek Sigeaon embankment, the grass is soft to bare feet, and from above they can watch the market vehicles cruising down the river. All the inhabitants of the area were very fortunate because the colonial authorities also built a typical Dutch dam to prevent the occurrence of major floods that had inundated the entire Rura Silindung.

3. The Standaardschool Mission School is located on the side of the road at the foot of the hills, has two classes of 20 to 25 students each, mostly from Lumbansoit and from Lumbansormin near Pangaribuan, Tarutung, while only a few children from Hutabarat 
are educated. In this very simple school, they were given Dutch language lessons, because it was precisely this subject that was most in demand. If after graduation there are students who want to continue their studies until grade six, then they are forced to move to Balige.

4. Dutch-language elementary school (Hollandsch Bataksche School), which later became HISdi Sigompulan-Tarutung. Since 1908, several zenders have provided Dutch language lessons as additional lessons for a number of elementary school graduates.

5. Nursing Course is a school that was established as a follow-up and development of medical services started by Batakmission doctors, since 1903 in Pearaja a nursing course was also held. With the arrival of a special teacher or Schwester from Germany, in 1905 a midwife course was opened in Pearaja Tarutung. In subsequent developments, these courses have increased their status to nurse and midwife schools in Tarutung and Balige. One of the objectives of the course and school administration is to combat the practice of medicine and childbirth by datu and sibaso (dukun beranak). The positive impact of this activity is that infant mortality has decreased sharply since the increase in the number of nurses and midwives who are scattered in various parts of Hutabarat village.

6. In 1927, the colonial government opened the first Dutch-language secondary school MULO (Meer Uitgebreid Lager Onderwijs) in Tarutung, the seat of the assistant resident of the Netherlands (the capital of the Toba region) and the center of the HKBP. With the opening of the school, parents hope that their children in the future can change their family's economy for the better.

The residents of the city thought that education could change their fate for the better and later they could be accepted as government employees. Thus it can be said that the mindset of society has advanced so that education is a top priority for their children.

The establishment of schools initiated by the Batakmission and the colonial government, succeeded in making the Batak people one of the ethnic groups who knew the letters best in the entire Dutch Indies colony compared to other regions in the archipelago. In the end, even though they only get schools at a low level, they will find it easy to find work outside the traditional field of work.

Meanwhile for general and vocational high school graduates, in addition to increasing economic welfare, it will increase their social status. Seeing such a huge opportunity to earn income and improve social status is the reason why people in Batak land send their children to school.

\section{c. Opened Transportation Lines}

The land road is the only main means of transportation in Tarutung City. Pathways and footpaths are increasingly important to accelerate the flow of transportation from one area to another. The colonial government acted as a scenario creator by exerting a lot of energy for the construction of these roads, both for the purpose of expanding colonies and for other purposes. Its construction starts from areas that have been controlled and then to independent areas that are included in their administrative areas. Along with the increasing importance of the territories in Tanah Batak for the colonial government, it encouraged these foreigners to open various transportation routes which were mainly used to transport the production of various types of plants.

The development of transportation routes that was initiated by the colonial government (even though it used local residents) helped increase the income and economic welfare of the community. Even though in the construction of these roads the Dutch colonial government needed many workers who came from the indigenous population and the community was exploited by forced labor (rodi / 'herrendiensten') which caused suffering to the community. 
The construction of new roads carried out by the colonial government was very beneficial not only for the foreign nation, but also for the people in Toba and Tarutung. The people's economic activity has increased quite significantly so that they are slowly feeling positive changes. After that, the Tarutung community no longer experienced difficulties in carrying out their economic activities because they were supported by new infrastructure, namely the opening of roads for trade routes in the region.

Right in the middle of the city, flows Aek Sigeaon, who for hundreds of years has passed faithfully dividing Tarutung in half. This river, whose water is yellowish, is very beneficial for the people of Tarutung although the river embankment was damaged. The government will immediately strengthen the embankment with a permanent wall, so that the danger of flooding can be anticipated. The construction of the bridge is very beneficial for the local population because it is very helpful and facilitates their trading activities, especially for marketing incense. The construction of Aek Sigeaon Tarutung was led by Insyinur F. Engel who became the architecture that built the road repair process from Tarutung to Balige as far as $95 \mathrm{~km}$.

With the formation of various new infrastructures, it has succeeded in pushing the city of Tarutung into an increasingly developing area and becoming one of the important areas in the Land of Batak. The land transportation road is the only main means of transportation in Tapanuli (except around Lake Toba). Roads are increasingly important to accelerate the flow of transportation from one area to another. The Dutch colonial government recruited Toba Batak people to work for the construction of the road, both for the purpose of expanding colonies and for other purposes. The road, which is usually taken within a few days of travel, after the conditions of the roads are better, the inter-regional relations will be smoother and the journey easier.

\section{Conclusion}

From the findings of this study, there are several things that can be drawn as conclusions regarding the development of the city of Tarutung. Before Tarutung was formed into a new city, during the traditional era the town of Tarutung was growing, a small village inhabited by the Batak-Toba people. Initially, these settlements started in the forests where big trees were their home. Traditional settlements for residents were built and surrounded by parik (fort fence) which served as a protection or barricade against enemy and wild animal attacks. The prevailing customary and cultural systems show that the village of Tarutung already has the characteristics of the formation of a traditional city. Tarutung Village was used as a center for trade transaction activities carried out with local residents or also immigrants from other areas. Tarutung is located in a strategic location and is profitable for trading activities because it is a cross-section of the Toba road that must be passed. Trade in forest and agricultural products is the main livelihood sector for the Tarutung people, such as camphor, incense and coffee. Trading activities take place at Onan Sitahuru Tarutung, which in addition to functioning as a place for the sale and purchase of goods bartering transactions also functions as a place for anesthetic meetings to be held attended by elders and kings in Tarutung to solve the customary problems of the Tarutung community. Trade in forest and agricultural products is the main livelihood sector for the Tarutung people, such as camphor, incense and coffee. Trading activities take place at Onan Sitahuru Tarutung which in addition to functioning as a place for the sale and purchase of goods bartering transactions also functions as a place for anesthetic meetings to be held attended by elders and kings in Tarutung to solve the customary problems of the Tarutung community. Trade in forest and agricultural products is the main livelihood sector for the Tarutung people, such as camphor, incense and coffee. Trading activities take place at Onan Sitahuru Tarutung which in addition 
to functioning as a place for the sale and purchase of goods bartering transactions also functions as a place for anesthetic meetings to be held attended by elders and kings in Tarutung to solve the customary problems of the Tarutung community.

The presence of Western colonialism in the form of religion, military, administration and economy was part of the driving force for the development of Tarutung City. The mission of Zending RMG gave birth to a new civilization in Tarutung by improving services in the education and health sectors. This is considered very effective as a step in making an approach to indigenous people as well as to facilitate the activities of zending people. They establish schools, hospitals. The zending understands that the people of Tarutung have already formed a social, cultural, religious and educational system. Through a long process the social system implemented by zending began to be implemented by the Tarutung community. They see that many of the things offered by RMG are more profitable or better answer the needs of the Tarutung people.

Missionary activity that spreads the gospel requires assurance of safety in order to continue in safety. In addition, the Dutch government also had an interest in extending its power to the Toba highlands. For the Dutch colonial government, the development of Christianity with the presence of RMG zending in Tarutung would make it easier for the Dutch to expand their power. The rule of Tarutung was legally announced by the Dutch government in 1876 that Tarutung was made a gubernemen area under the residents of Tapanuli. In 1879, the city of Tarutung was designated as Onderafdeling Silindung administrative center which placed a controller to carry out various activities of the colonial government.

Changes in administration and implementation of all activities of the Dutch government resulted in the fulfillment of new needs for supporting facilities. The Netherlands builds various facilities that are directly related to supporting the government as well as indirect facilities that support the life of the people of the ruling class. Some of the facilities built by Tarutung include the growth of a market with various economic activities, the construction of hospitals, the establishment of new schools, the construction of transportation routes for trade. The establishment of these new infrastructures eventually developed Tarutung into a city that has various important facilities in its area. After the formation of Tarutung into a new city, it was felt by its inhabitants who experienced a change of life towards a modern direction. Other than that, Tarutung residents also began to feel the economic changes for the better. The Tarutung community began to experience economic changes for the better because access made it easier for them to carry out their activities.

\section{References}

Aritonang, S Jan. 1988. Sejarah Pendidikan Kristen di Tanah Batak. Kwitang: PT. BPK. Gunung Mulia Jakarta

Basundoro, Purnawarman. 2012. Sejarah Kota.Yogyakarta : Ombak.

Castels, Lance. 2001. Kehidupan Politik Suatu Karasedinan di Sumatera, Tapanuli. 19151940. Jakarta: Kepustakaan Populer Gramedia (KPG)

Colombijn, Freekdkk. 2005.Kota Lama, Kota Baru Sejarah Kota-Kota Di Indonesia Sebelum Dan Setelah Kemerdekaan.Yogyakarta : Ombak.

Colombijin, Freek. 2006. Paco-Paco (Kota) Padang. Yogyakarta: Ombak.

Daniel, Perret.2010. Kolonialisme dan Etnisitas Batak dan Melayu di Sumatra Timu Laut. Jakarta: Kepustakaan Populer Gramedia.

Djunaedi Achmad. 2014. Pengantar Perencanaan Wilayah dan Kota.Yogyakarta: Gadja Mada University Press. 
Firdaus,Rifki. 2010. Perkembangan Kota Padang 1870-1945. Skripsi Sarjana, Depok: Fakultas Ilmu Budaya Universitas Indonesia.

Harahap, E. 1960. Perihal Bangsa Batak.Jakarta:Dep.PPdanK.

Kholil, S., Zulkarnain, I., and Simamora, I.Y. (2021). The Existence of Women in the Batak Angkola Family in North Padang Lawas. Budapest International Research and Critics Institute-Journal (BIRCI-Journal) Vol 4 (1): 827-837.

Kozok, Uli. 2010. Utusan Damai di Kemelut Perang Peran Zending dalam Perang Toba : Jakarta, Yayasan Pustaka Obor Indonesia.

Kurris, R . 2006. Pelangi di Bukit Barisan. Yogyakarta: KANISIUS.

Manalu, Ismail. 1985. Mengenal Batak. Medan: C.V Kiara.

Napitupulu, O.L. 1972. Perang Batak Perang Sisingamangaraja. Jakarta: Yayasan Pahlawan Nasional Sisingamangaraja.

Nas,Peter J.M dan Welmoet Boender. 2007. "Kota Indonesia dalam Teori Perkotaan"dalam Kota-Kota Indonesia Bunga Rampai. Yogyakarta; Gajah Mada University

Onggang ParlindunganMangaraja. 2007.TuankuRao.Yogyakarta:LkiS Pelangi Aksara Yogyakarta.

Pasaribu, Patar. 2004. Dr. Ingwer Ludwig. Nommensen Apostel di Tanah Batak.Medan: Percetakan Universitas HKBP Nommensen.

Priyadi, Sugeng. 2012. Sejarah Lokal, Konsep Metode dan Tantangannya, Yogyakarta: Ombak.

Raplan, Jubil. 2004. Menggapai gereja Inklusif: Bunga Rampai Penghargaan atas Pengabdian Pdt Dr JH Hutauruk. Tarutung: Kantor Pusat HKBP Pearaja Tarutung.

Raplan, Jubil. 2009. Sejarah Pelayanan Diakonal di Tanah Batak (1875-2011). Pematang Siantar : Unit Usaha Percetakan HKBP Pematang Siantar.

Raplan, Jubil. 2011. Lahir, Berakar dan Bertumbuh di dalam Kristus. Sejarah 150 Tahun Huria Kristen Batak Protestan 7 Oktober 1861- 7 Oktober 2011.Tarutung: Kantor Pusat HKBP Pearaja Tarutung.

Said, Mohammad. 1961. Tokoh Sisingamangaraja II. Medan: Waspada.

Sangti, Batara. 1977. Sejarah Batak. Balige: Karl Sianipar Company.

Schreiner,Lothar. 2010. Adat dan Injil. Perjumpaan Adat dengan Iman Kristen Di tanah Batak. Trans. P.S. Naipospos, Th.van den End \& J.S. Aritonang. Jakarta: Gunung Mulia

Siahaan, Bisuk.2005. Batak-Toba. Kehidupan Di Balik Tembok Bambu. Jakarta: Kempala Foundation.

Siahaan, Nalom. 1964. Sedjarah Kebudajaan Batak. Medan: C.V.Napitupulu \& Sons

Simanjuntak, Bungaran. 2006. Struktur Sosial dan Sistem Politik Batak Toba hingga 1945, Jakarta: Yayasan Pustaka Obor Indonesia.

Situmorang, Sitor. 1993. Toba Na Sae.Jakarta : Pustaka Sinar Harapan. 